\title{
Detoxification of the Fumonisin Mycotoxins in Maize: An Enzymatic Approach
}

\author{
Johanna Alberts $1, *(\mathbb{1})$, Gerd Schatzmayr ${ }^{2}\left(\mathbb{D}\right.$, Wulf-Dieter Moll ${ }^{2}\left(\mathbb{0}\right.$, Ibtisaam Davids ${ }^{1,3}$, \\ John Rheeder $^{1}{ }^{\mathbb{D}}$, Hester-Mari Burger ${ }^{1}$, Gordon Shephard ${ }^{1}$ and Wentzel Gelderblom ${ }^{1,4}$ \\ 1 Mycotoxicology Research Group, Institute of Biomedical and Microbial Biotechnology, Cape Peninsula \\ University of Technology, Bellville 7535, South Africa \\ 2 BIOMIN Research Center, BIOMIN, Technopark 1, 3430 Tulln, Austria \\ 3 Department of Biomedical Science, University of the Western Cape, Bellville 7535, South Africa \\ 4 Department of Biochemistry, Stellenbosch University, Stellenbosch 7600, South Africa \\ * Correspondence: albertsh@cput.ac.za
}

Received: 31 July 2019; Accepted: 23 August 2019; Published: 10 September 2019

check for

\begin{abstract}
Enzymatic detoxification has become a promising approach for control of mycotoxins postharvest in grains through modification of chemical structures determining their toxicity. In the present study fumonisin esterase FumD (EC 3.1.1.87) (FUMzyme ${ }^{\circledR}$; BIOMIN, Tulln, Austria), hydrolysing fumonisin (FB) mycotoxins by de-esterification, was utilised to develop an enzymatic reduction method in a maize kernel enzyme incubation mixture. Efficacy of the FumD FB reduction method in "low" and "high" FB contaminated home-grown maize was compared by monitoring $\mathrm{FB}_{1}$ hydrolysis to the hydrolysed $\mathrm{FB}_{1}\left(\mathrm{HFB}_{1}\right)$ product utilising a validated LC-MS/MS analytical method. The method was further evaluated in terms of enzyme activity and treatment duration by assessing enzyme kinetic parameters and the relative distribution of $\mathrm{HFB}_{1}$ between maize kernels and the residual aqueous environment. FumD treatments resulted in significant reduction $(\geq 80 \%)$ in "low" ( $\geq 1000 \mathrm{U} / \mathrm{L}, p<0.05)$ and "high" (100 U/L, $p<0.05 ; \geq 1000 \mathrm{U} / \mathrm{L}, p<0.0001)$ FB contaminated maize after $1 \mathrm{~h}$ respectively, with an approximate 1:1 $\mu$ mol conversion ratio of $\mathrm{FB}_{1}$ into the formation of $\mathrm{HFB}_{1}$. Enzyme kinetic parameters indicated that, depending on the activity of FumD utilised, a significantly $(p<0.05)$ higher $\mathrm{FB}_{1}$ conversion rate was noticed in "high" FB contaminated maize. The FumD FB reduction method in maize could find application in commercial maize-based practices as well as in communities utilising home-grown maize as a main dietary staple and known to be exposed above the tolerable daily intake levels.
\end{abstract}

Keywords: fumonisin; enzymatic detoxification; fumonisin esterase FumD; enzyme kinetics; maize

Key Contribution: A fumonisin B (FB) reduction method was developed for whole maize utilizing fumonisin esterase FumD (BIOMIN; Tulln; Austria). Depending on the enzyme activity and duration of treatment; reduction of FB in maize could be achieved $\geq 80 \%$ with an approximate 1:1 $\mu$ molar conversion ratio of $\mathrm{FB}_{1}$ to hydrolysed $\mathrm{FB}_{1}\left(\mathrm{HFB}_{1}\right)$. The FumD FB reduction method could find application in populations exposed to maize containing FB above international regulatory levels as well as in industrial processes utilising high FB contaminated maize.

\section{Introduction}

The lack of effective and environmentally safe chemical control methods against fungal infection and mycotoxin production in maize initiated investigations into biologically safe alternatives to prevent these contaminants from entering the food chain [1]. Methods involve the application of natural resources, including plant material, microbial cultures, genetic material, clay minerals 
and enzymes [2-11]. Enzymatic degradation of mycotoxins in food sources, postharvest, is a new research approach, providing many opportunities for novel initiatives to improve the safety of food with respect to mycotoxin reduction [1,12]. The focus is on targeted modification of the chemical structures by enzymatic cleavage or conversion of chemical bonds/groups that play a key role during cytotoxicity $[13,14]$. Detoxification of the fumonisins is achieved by enzymatic deamination of the free amino group at C-2 and de-esterification of the ester bonds at C-14 and C-15. A knowledge base on reduction of mycotoxin concentrations by bacterial and fungal cultures has been established over the years [14-17]. This information was further developed by identifying microbial enzymes responsible for detoxification, characterization of genes encoding the enzymes, expression of genes in food-grade microorganisms, and development of culture and recombinant enzyme preparations for commercial application. Microorganisms and enzymes capable of degrading fumonisin $\mathrm{B}_{1}\left(\mathrm{FB}_{1}\right)$ include carboxylesterase and amino oxidase enzymes of Exophiala spinifera ATCC 74269, Rhinocladiella atrovirens ATCC 74270 as well as carboxylesterase and aminotransferase enzymes of Bacterium ATCC 55552 and Sphingopyxis macrogoltabida MTA144 [14-19].

Recently, a commercial fumonisin esterase FumD (EC 3.1.1.87) (FUMzyme ${ }^{\circledR}$; BIOMIN, Tulln, Austria) capable of effectively hydrolysing the tricarballylic acid groups of $\mathrm{FB}_{1}$ yielding hydrolysed $\mathrm{FB}_{1}$ $\left(\mathrm{HFB}_{1}\right)$, was introduced. The enzyme activity is specific and irreversible, while $\mathrm{HFB}_{1}$ exhibited less toxic effects when evaluated in pig intestine, as indicated by disruption of the sphinganine/sphingosine ratios in the liver and plasma, induction of an intestinal immune response, the absence of hepatotoxicity, and changes in intestinal morphology [20]. FUMzyme ${ }^{\circledR}$ has been regarded safe for humans, animals and the environment by the European Food Safety Authority (EFSA) [21]. Although enzymatic detoxification has become a promising approach and found application in the animal feed industry [21-24], a broader application to safeguard human food still has to be investigated. Such an approach could add value to commercial maize-based manufacturing processes during which the fumonisins are concentrated in certain products and co-products, as well as in subsistence farming communities where people are exposed to unacceptable levels of the fumonisins in their staple diet.

The present study describes the development of a FumD FB reduction method utilising home-grown maize batches containing "low" and "high" levels of FB. The efficacy of the reduction method was determined by monitoring the extent of $\mathrm{FB}_{1}$ hydrolysis and the formation of $\mathrm{HFB}_{1}$ in residual maize kernels and enzyme solutions utilising a validated LC-MS/MS analytical method. The FumD FB reduction method was optimized in terms of enzyme activity and treatment duration considering specific enzyme kinetic parameters to evaluate differences between maize samples with varying FB levels. Distribution of $\mathrm{HFB}_{1}$ between the kernel and aqueous phase was also recorded.

\section{Results}

\subsection{Validation of The Extraction and Chromatographic Quantification Methods}

The method validation parameters are summarised in Tables 1 and 2. The lower limit of quantification (LOQ) for each fumonisin was determined from a signal to noise $(\mathrm{s} / \mathrm{n})$ ratio of at least five times the response compared to the blank response. Analyte responses were identifiable, discrete and reproducible. LOQ values for the individual fumonisins ranged between $2.8-3.5 \mu \mathrm{g} / \mathrm{kg}$. Linearity $\left(\mathrm{r}^{2}\right)$ of the fumonisin calibration curve was $>0.998$. Selectivity of the method was confirmed by demonstrating no interfering peaks at LOQ for each of the fumonisins. Accuracy was determined by replicate analysis of samples containing known amounts of analyte, resulting in means within 15\% from the theoretical values. Recoveries were calculated by comparison of the response obtained for each mycotoxin with that of known spiked concentrations in blank maize, expressed as a percentage. The recoveries for the individual fumonisins ranged from $79-84 \%$ and were consistent and reproducible. Fumonisin concentrations in the FAPAS quality control reference maize samples were always within the stipulated ranges for each fumonisin (data not shown). 
Table 1. LC-MS/MS conditions for quantification of fumonisins and hydrolysed fumonisin $b_{1}$ by positive ESI at $3.5 \mathrm{kv}$ capillary voltage.

\begin{tabular}{ccccc}
\hline Analyte & $\begin{array}{c}\text { Cone } \\
\text { Voltage }\end{array}$ & Precursor & $\begin{array}{c}\text { Quantifier } \\
\text { (Collision Energy) }\end{array}$ & $\begin{array}{c}\text { Qualifier } \\
\text { (Collision Energy) }\end{array}$ \\
\hline Fumonisin $B_{1}$ & 50 & 722.3 & $334.3(40)$ & $352.3(38)$ \\
\hline $\begin{array}{c}\text { Fumonisins } B_{2} \\
\text { and } B_{3}\end{array}$ & 50 & 706.3 & $318.3(40)$ & $336.3(40)$ \\
\hline $\begin{array}{c}\text { Hydrolysed } \\
\text { fumonisin } B_{1}\end{array}$ & 25 & 406.6 & $334.3(25)$ & $352.4(20)$ \\
\hline
\end{tabular}

Table 2. Validation of the analytical method for fumonisin analyses in maize.

\begin{tabular}{ccccc}
\hline Analyte & LOQ $(\mu \mathrm{g} / \mathbf{k g})$ & Spike Level $(\mu \mathrm{g} / \mathbf{k g})$ & Recovery $(\%)$ & RSDr $(\%)$ \\
\hline Fumonisin $B_{1}$ & 3.5 & 1060 & 84 & 2 \\
\hline Fumonisin $B_{2}$ & 2.8 & 925 & 66 & 4 \\
\hline Fumonisin $B_{3}$ & 2.8 & 520 & 79 & 1 \\
\hline Hydrolysed fumonisin $B_{1}$ & 2.8 & 800 & 80 & 2 \\
\hline
\end{tabular}

LOQ, lower limit of quantification; RSDr, relative standard deviation for repeatability.

\section{2. $F B$ and $H F B_{1}$ Concentrations in Maize}

$\mathrm{FB}$ and $\mathrm{HFB}_{1}$ concentrations $(\mu \mathrm{g} / \mathrm{kg})$ (mean values and standard deviations in brackets) in untreated "low" FB contaminated maize: $\mathrm{FB}_{1}, 3326$ (1588); $\mathrm{FB}_{2}, 1503$ (749); $\mathrm{FB}_{3}, 530$ (376); and $\mathrm{HFB}_{1}$, 182 (106). Concentrations in "high" FB contaminated maize: $\mathrm{FB}_{1}, 9343$ (1756); $\mathrm{FB}_{2}, 3559$ (541); $\mathrm{FB}_{3}$, 1701 (1557); and $\mathrm{HFB}_{1}, 342$ (137). FB concentrations in "low" and "high" FB contaminated FumD treated maize are summarised in Figure 1 (Table insert). The HFB 1 levels in the "low" and "high" FB contaminated FumD treated maize were 12 (8) and 65 (59), respectively. High variation in the FB levels existed between subsamples within each of the two maize batches, which is a common phenomenon for this type of analyses mainly due to the random distribution of infected kernels throughout a specific sample $[25,26]$.

\subsection{Optimal FumD activity and Conversion Ratios (Fixed Time Incubation)}

2.3.1. $\mathrm{FB}_{1}$ Hydrolysis and Formation of $\mathrm{HFB}_{1}$ in Residual Maize Kernels as a Function of Fumd Activity

The $\mathrm{pH}$ of maize-enzyme solutions before and after $1 \mathrm{~h}$ enzyme treatments were $5.1 \pm 0.10$ and $4.8 \pm 0.04$ respectively for "low" FB contaminated maize. For the "high" FB contaminated maize it was $5.7 \pm 0.12$ and $5.4 \pm 0.04$.

When compared to the water control sample in the absence of the enzyme, the total $\mathrm{FB}\left(\mathrm{FB}_{1}\right.$, $\mathrm{FB}_{2}$ and $\mathrm{FB}_{3}$ ) concentrations were reduced as a function of an increased enzyme activity during a $1 \mathrm{~h}$ incubation in both the "low" and "high" FB contaminated maize (Figure 1A,B). Treatment with $\geq 1000 \mathrm{U} / \mathrm{L}$ resulted in an $80 \%$ reduction in total FB concentrations (Figure 1, table insert) when compared to the water control. Incubations of "low" FB contaminated maize with 10 and $100 \mathrm{U} / \mathrm{L}$ FumD markedly $(p>0.05)$ reduced $\mathrm{FB}_{1}$ when compared to the water control incubation (Figure $\left.1 \mathrm{~A}\right)$. A significant reduction in $\mathrm{FB}_{1}$ was observed with $1000 \mathrm{U} / \mathrm{L}$ and $5000 \mathrm{U} / \mathrm{L}$ when compared to the water control $(p<0.05)$, with no significant difference $(p>0.05)$ between the two incubations. The reduction in $\mathrm{FB}_{1}$ concentrations coincided with a significant increase in $\mathrm{HFB}_{1}$ concentrations from $10 \mathrm{U} / \mathrm{L}(p<0.01)$ to $1000 \mathrm{U} / \mathrm{L}(p<0.001)$ and $5000 \mathrm{U} / \mathrm{L}(p<0.001)$, when compared to the water control. Only trace amounts of $\mathrm{HFB}_{1}$ were detected in the water control samples of "low" FB contaminated maize. 
A

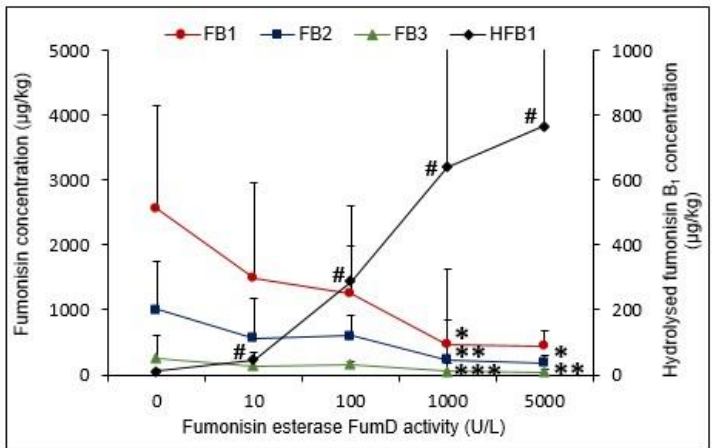

B

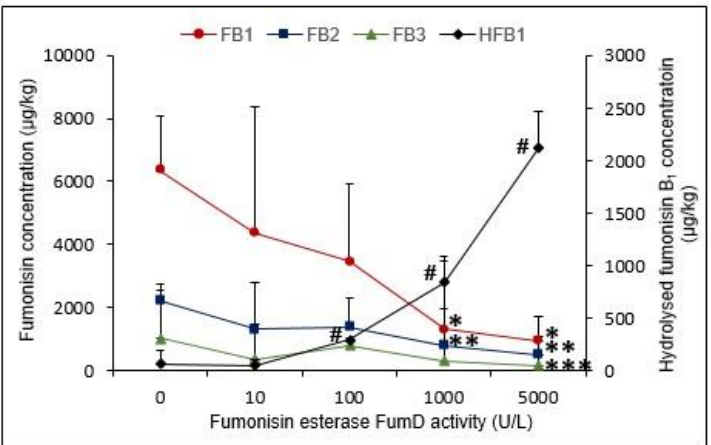

\begin{tabular}{|l|c|c|c|c|c|c|c|c|c|c|}
\hline & \multicolumn{9}{|c|}{ "Low" FB contaminated maize } & \multicolumn{4}{c|}{ "High" FB contaminated maize } \\
\hline FumD activity (U/L) & Control & $\mathbf{1 0}$ & $\mathbf{1 0 0}$ & $\mathbf{1 0 0 0}$ & $\mathbf{5 0 0 0}$ & Control & $\mathbf{1 0}$ & $\mathbf{1 0 0}$ & $\mathbf{1 0 0 0}$ & $\mathbf{5 0 0 0}$ \\
\hline \multirow{2}{*}{ Total FB $(\mu \mathrm{g} / \mathrm{kg})$} & 3813 & 2192 & 2007 & 764 & 666 & 11604 & 4706 & 4242 & 2106 & 1533 \\
& $(2167)$ & $(1079)$ & $(1858)$ & $(366)$ & $(473)$ & $(4169)$ & $(1740)$ & $(2534)$ & $(982)$ & $(767)$ \\
\hline \multirow{2}{*}{ \% Reduction } & - & 41 & 69 & $80^{*}$ & $82^{*}$ & - & 60 & 56 & $82^{*}$ & $87^{*}$ \\
& & $(29)$ & $(16)$ & $(10)$ & $(12)$ & & $(16)$ & $(17)$ & $(8)$ & $(7)$ \\
\hline
\end{tabular}

Figure 1. Fumonisin $\mathrm{B}\left(\mathrm{FB}_{1}, \mathrm{FB}_{2}, \mathrm{FB}_{3}\right)$ and hydrolysed fumonisin $\mathrm{B}_{1}\left(\mathrm{HFB}_{1}\right)$ concentrations $(\mu \mathrm{g} / \mathrm{kg})$ maize as a function of fumonisin esterase FumD activity $(0,10,100,1000$ and $5000 \mathrm{U} / \mathrm{L})$ after $1 \mathrm{~h}$ treatment. (A) "Low" and (B) "High" FB contaminated maize. Values represent means of three to five replications of experiments and error bars indicate standard deviations. The statistical analyses are based on natural $\log (\ln )$ transformations. The ${ }^{*}, * * * *$ and ${ }^{\#}$ indicate significant $(p<0.05)$ differences of means from the water control $(0 \mathrm{U} / \mathrm{L})$ treatments. Table insert: \% total reduction of the total FB as a function of enzyme actvity after $1 \mathrm{~h}$ in "low" and "high" FB contaminated maize. Standard deviations are in brackets.

In "high" FB contaminated maize, a significant reduction in $\mathrm{FB}_{1}$ was observed at FumD activities of $100 \mathrm{U} / \mathrm{L}(p<0.05), 1000 \mathrm{U} / \mathrm{L}(p<0.0001)$ and $5000 \mathrm{U} / \mathrm{L}(p<0.0001)$ when compared to the water control with no significant $(p>0.05)$ differences between the different incubations (Figure 1B). The total FB concentrations (Figure 1B Table insert) were again reduced by $\geq 80 \%$ at the two highest FumD concentrations. Incubation with $10 \mathrm{U} / \mathrm{L}$ FumD only markedly reduced the $\mathrm{FB}_{1}$ concentration while incubation with $1000 \mathrm{U} / \mathrm{L}$ resulted in $79 \%$ reduction in $\mathrm{FB}_{1}$, and $82 \%$ reduction in total $\mathrm{FB}$ concentrations, respectively. The reduction in $\mathrm{FB}_{1}$ again coincided with a significant $(p<0.0001)$ increase in $\mathrm{HFB}_{1}$ concentrations with treatments $\geq 100 \mathrm{U} / \mathrm{L}$, while only trace amounts of $\mathrm{HFB}_{1}$ were detected in the water control.

\subsection{2. $\mathrm{FB}_{1}$ Hydrolysis and Formation of $\mathrm{Hfb}_{1}$ in the Residual Solutions as a Function of Fumd Activity}

Residual water control samples obtained from the "low" FB contaminated maize contained high $\mathrm{FB}$ and low $\mathrm{HFB}_{1}$ concentrations (Figure $2 \mathrm{~A}$ ). FumD reduced $(p<0.05) \mathrm{FB}$ as a function of increased enzyme activity. The reduction in $\mathrm{FB}_{1}$ coincided with a significant increase in $\mathrm{HFB}_{1}$ from $10 \mathrm{U} / \mathrm{L}$ $(p<0.01)$ reaching a maximum at $100 \mathrm{U} / \mathrm{L}$ with no further increase $>100 \mathrm{U} / \mathrm{L}$. Treatment with $10 \mathrm{U} / \mathrm{L}$ resulted in an almost complete removal of $\mathrm{FB}_{1}$, with almost no $\mathrm{FB}_{1}$ detected $\geq 100 \mathrm{U} / \mathrm{L}$. Complete reduction of $\mathrm{FB}_{2}$ and $\mathrm{FB}_{3}$ was also observed $\geq 10 \mathrm{U} / \mathrm{L}$. A similar trend was observed in residual water control and enzyme solutions of the "high" FB contaminated maize, although $\mathrm{FB}_{1}$ was only completely removed $>1000 \mathrm{U} / \mathrm{L}$ (Figure $2 \mathrm{~B}$ ). Total reduction of $\mathrm{FB}_{2}$ and $\mathrm{FB}_{3}$ was observed with $\geq 100 \mathrm{U} / \mathrm{L}$ FumD activity. A significant $(p<0.05)$ increase in $\mathrm{HFB}_{1}$ was noticed $\geq 10 \mathrm{U} / \mathrm{L}$, reaching a maximum at $100 \mathrm{U} / \mathrm{L}$. 
A

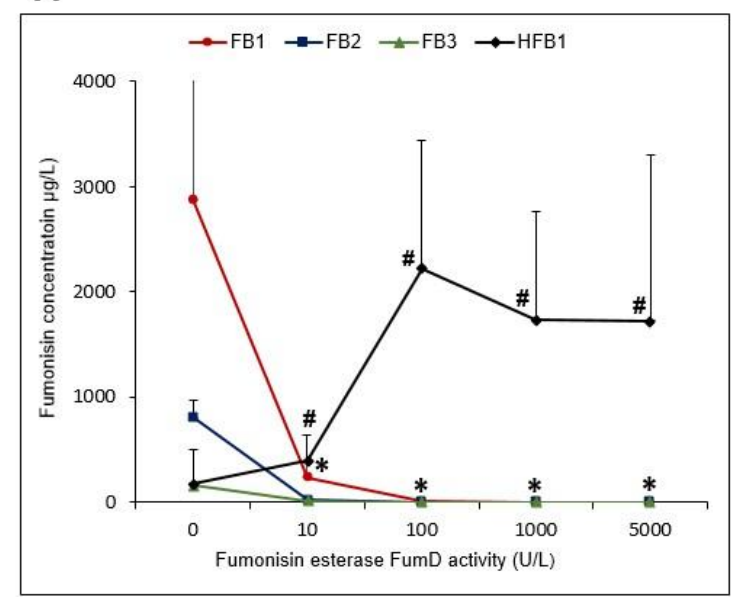

B

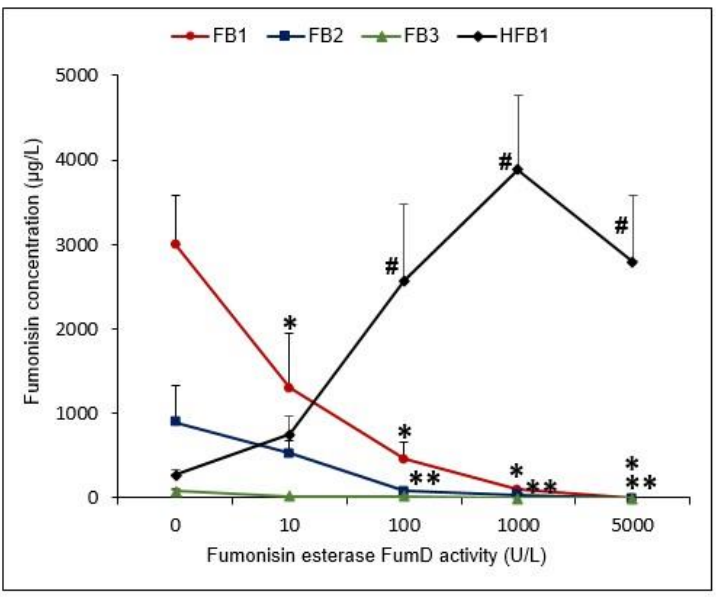

Figure 2. $\mathrm{FB}\left(\mathrm{FB}_{1}, \mathrm{FB}_{2}, \mathrm{FB}_{3}\right)$ and hydrolysed fumonisin $\mathrm{B}_{1}\left(\mathrm{HFB}_{1}\right)$ concentrations in residual water control and enzyme solutions as a function of fumonisin esterase FumD activity $(0,10,100,1000$ and $5000 \mathrm{U} / \mathrm{L}$ ) after $1 \mathrm{~h}$ treatment. (A) “Low" and (B) “High" FB contaminated maize. Values represent means of three to five replications of experiments and error bars indicate standard deviations. The statistical analyses are based on natural $\log (\ln )$ transformations. The ${ }^{*},{ }^{* *}$ and ${ }^{\#}$ indicate significant $(p<0.05)$ differences of means from the respective water control $(0 \mathrm{U} / \mathrm{L})$ treatments.

\subsection{3. $\mathrm{FB}_{1}$ Hydrolysis Relative to the Formation of $\mathrm{HFB}_{1}$}

When considering the total mean $\mathrm{FB}_{1}$ levels in the incubation mixtures (levels in residual maize kernels plus residual solutions expressed in micromoles), it was markedly to significantly $(p<0.05)$ higher in "high" FB contaminated maize although it varied when utilizing the different enzyme incubations (Table 3). Although the mean $\mathrm{FB}_{1}$ converted were similar between both samples treated with the various FumD activities, the $\% \mathrm{FB}_{1}(\mu \mathrm{mol})$ loss was significantly $(p<0.05)$ higher in "low" FB contaminated maize at the two lower enzyme activities with no difference when using higher FumD activities $(\geq 1000 \mathrm{U} / \mathrm{L})$. Overall, FumD significantly $(p<0.05)$ increased the mean total $\mathrm{HFB}_{1}$ levels in both samples as a function of the enzyme activity reaching a maximum level $\geq 100 \mathrm{U} / \mathrm{L}$. When considering the $\mathrm{FB}_{1}: \mathrm{HFB}_{1}$ conversion ratio, FumD resulted in a markedly lower conversion at $10 \mathrm{U} / \mathrm{L}$ in "low" as compared to "high" FB contaminated maize. The $\mathrm{FB}_{1}: \mathrm{HFB}_{1}$ conversion ratios were similar with $100 \mathrm{U} / \mathrm{L}$, reaching approximately a 1:1 ratio at $\geq 1000 \mathrm{U} / \mathrm{L}$, implying maximum conversion.

\subsubsection{Relative $\mathrm{HFB}_{1}$ Distribution in Residual Maize Kernels and Solutions Following} FumD Incubations

The total $\mathrm{HFB}_{1}$ in the incubation mixture increased significantly $(p<0.05)$ in incubation $\geq 100 \mathrm{U} / \mathrm{L}$ FumD activities with no difference at higher enzyme activities and/or between the "low" and "high" FB contaminated maize samples. The $\% \mathrm{HFB}_{1}$ accumulation in the "low" FB contaminated maize increased as a function of increased FumD activity reaching a maximum level at the 1000 U/L (Table 4). A similar response was noticed in the "high" FB contaminated maize showing a typical dose response effect with a significant $(p<0.05)$ higher level obtained with $5000 \mathrm{U} / \mathrm{L}$ FumD activity. Maximum levels when considering the $\%$ total mean $\mathrm{HFB}_{1}$ were noticed in the residual solution up to $100 \mathrm{U} / \mathrm{L}$ FumD, which markedly and significantly decreased in the "low" and "high" FB contaminated samples at higher FumD activities, respectively. 
Table 3. Comparative $\mathrm{FB}_{1}$ conversion relative to $\mathrm{HFB}_{1}$ formation between "low" and "high" FB contaminated maize during $1 \mathrm{~h}$ incubation with different FumD activities.

\begin{tabular}{|c|c|c|c|c|c|}
\hline $\begin{array}{l}\text { FumD } \\
\text { Aactivity (U/L) }\end{array}$ & $\begin{array}{c}\text { Total Mean } \mu \text { mol } \\
\text { FB }_{1} \text { in Incubation } \\
\text { Mixture * }^{*}\end{array}$ & $\begin{array}{c}\text { Mean } \mu \mathrm{mol} \\
\mathrm{FB}_{1} \text { Converted }\end{array}$ & $\begin{array}{l}\text { Mean } \mu \mathrm{mol} \mathrm{FB}_{1} \\
\text { Loss }(\%)\end{array}$ & $\begin{array}{c}\text { Total Mean } \mu \mathrm{mol} \\
\mathrm{HFB}_{1} \text { in Incubation } \\
\text { Mixture }\end{array}$ & $\begin{array}{c}\mathrm{FB}_{1}: \mathrm{HFB}_{1} \mu \mathrm{mol} \\
\text { Conversion Ratio }\end{array}$ \\
\hline \multicolumn{6}{|c|}{ "Low" FB Contaminated Maize } \\
\hline 0 ** & $1.15 \pm 0.55$ & - & - & $0.02 \pm 0.01$ & $42.75 \pm 12.14$ \\
\hline 10 & $0.27 \pm 0.14^{\mathrm{ab}}$ & $0.88 \pm 0.14^{\mathrm{a}}$ & $76.58 \pm 11.90^{a b c}$ & $0.13 \pm 0.05^{\mathrm{a}}$ & $7.22 \pm 2.40^{\mathrm{a}}$ \\
\hline 100 & $0.18 \pm 0.16^{\mathrm{ac}}$ & $0.98 \pm 0.16^{\mathrm{a}}$ & $84.73 \pm 14.14^{\mathrm{ab}}$ & $0.94 \pm 0.62^{b}$ & $2.52 \pm 0.84^{\mathrm{ab}}$ \\
\hline 1000 & $0.07 \pm 0.03^{c}$ & $1.09 \pm 0.03^{\mathrm{ab}}$ & $94.32 \pm 2.91^{\mathrm{a}}$ & $0.99 \pm 0.60^{b}$ & $1.30 \pm 0.58 \mathrm{bc}$ \\
\hline 5000 & $0.06 \pm 0.05^{c}$ & $1.09 \pm 0.05^{\mathrm{ab}}$ & $94.64 \pm 3.98 \mathrm{ab}$ & $1.02 \pm 1.00^{b}$ & $0.66 \pm 0.32^{c}$ \\
\hline \multicolumn{6}{|c|}{ "High" FB Contaminated Maize } \\
\hline 0 ** & $1.74 \pm 1.32$ & - & - & $0.16 \pm 0.10$ & $10.23 \pm 3.96$ \\
\hline 10 & $0.97 \pm 0.50^{b}$ & $0.76 \pm 0.50^{\mathrm{a}}$ & $55.04 \pm 17.68^{c}$ & $0.24 \pm 0.15^{a}$ & $3.4 \pm 1.73^{a b d}$ \\
\hline 100 & $0.71 \pm 0.37^{b}$ & $1.02 \pm 0.37^{\mathrm{a}}$ & $58.84 \pm 21.59^{c}$ & $1.17 \pm 0.53^{b}$ & $1.38 \pm 0.72 \mathrm{bc}$ \\
\hline 1000 & $0.21 \pm 0.16^{\mathrm{ac}}$ & $1.52 \pm 0.16^{b}$ & $87.75 \pm 9.31 \mathrm{ab}$ & $1.96 \pm 0.89^{b}$ & $0.93 \pm 0.46^{c}$ \\
\hline 5000 & $0.13 \pm 0.07^{\mathrm{ac}}$ & $1.61 \pm 0.07^{b}$ & $92.61 \pm 4.09 \mathrm{ab}$ & $1.68 \pm 0.66^{b}$ & $1.11 \pm 0.54^{\mathrm{cd}}$ \\
\hline
\end{tabular}

The statistical analyses are based on natural $\log (\ln )$ transformations. Values represent means \pm standard deviations of three to five replications of experiments. Statistical differences $(p<0.05)$ in a column for FumD activities within and between the "low" and "high" FB contaminated maize are indicated with different letters. * Combined FB 1 levels in maize and residual enzyme solution. ${ }^{* *}$ Shaded areas represent the water control treatment $(0 \mathrm{U} / \mathrm{L})$. HFB 1 levels were corrected accordingly in the presence of the enzyme.

Table 4. Distribution of $\mathrm{HFB}_{1}$ between residual maize and the solution following FumD treatment of "low" and "high" FB contaminated maize for $1 \mathrm{~h}$.

\begin{tabular}{|c|c|c|c|c|}
\hline $\begin{array}{l}\text { FumD } \\
\text { Activity } \\
\text { (U/L) }\end{array}$ & $\begin{array}{c}\text { Total Mean } \mathrm{HFB}_{1} \\
(\mu \mathrm{mol}) \text { in } 100 \mathrm{~g} \\
\text { Residual Maize Kernels }\end{array}$ & $\begin{array}{l}\text { Total Mean } \mathrm{HFB}_{1} \\
(\mu \mathrm{mol}) \text { in } 200 \mathrm{~mL} \\
\text { Residual Solution }\end{array}$ & $\begin{array}{c}\text { Mean } \mu \mathrm{mol} \mathrm{HFB} \\
\text { in Residual Maize } \\
\text { Kernels (\%) }\end{array}$ & $\begin{array}{c}\text { Mean } \mu \text { mol } \mathrm{HFB}_{1} \\
\text { in Residual } \\
\text { Solution (\%) }\end{array}$ \\
\hline & \multicolumn{4}{|c|}{ “Low" FB Contaminated Maize } \\
\hline 10 & $0.01 \pm 0.01^{\mathrm{a}}$ & $0.13 \pm 0.04^{\mathrm{a}}$ & $5.65 \pm 3.47^{\mathrm{a}}$ & $94.35 \pm 3.47^{\mathrm{a}}$ \\
\hline 100 & $0.07 \pm 0.06^{b}$ & $0.87 \pm 0.58^{b}$ & $7.35 \pm 3.28^{a}$ & $92.65 \pm 3.28^{a}$ \\
\hline 1000 & $0.15 \pm 0.11^{b}$ & $0.83 \pm 0.50^{b}$ & $15.82 \pm 4.48^{b}$ & $84.18 \pm 4.48^{b}$ \\
\hline \multirow[t]{2}{*}{5000} & $0.19 \pm 0.22^{b}$ & $0.83 \pm 0.78^{b}$ & $16.25 \pm 3.86^{b}$ & $83.75 \pm 3.86^{b}$ \\
\hline & \multicolumn{4}{|c|}{ “High" FB Contaminated Maize } \\
\hline 10 & $0.00^{\mathrm{a}}$ & $0.24 \pm 0.14^{\mathrm{a}}$ & $0.48 \pm 0.58^{a}$ & $99.52 \pm 0.60^{a}$ \\
\hline 100 & $0.08 \pm 0.06^{b}$ & $1.09 \pm 0.48^{b}$ & $6.75 \pm 2.24^{b}$ & $93.25 \pm 2.24^{b}$ \\
\hline 1000 & $0.19 \pm 0.09^{b c}$ & $1.77 \pm 0.86^{b}$ & $10.68 \pm 4.33^{b}$ & $89.32 \pm 4.33^{b}$ \\
\hline 5000 & $0.50 \pm 0.17^{c}$ & $1.17 \pm 0.65^{b}$ & $32.90 \pm 11.85^{c}$ & $67.10 \pm 11.90^{c}$ \\
\hline
\end{tabular}

The statistical analyses are based on natural $\log (\ln )$ transformations. Values represent means \pm standard deviations of three to five replications of experiments. Statistical differences $(p<0.05)$ in a column of the $\% \mathrm{HFB}_{1}$ distribution within "low" and "high" FB contaminated maize are indicated with different letters.

\subsection{Comparative Enzyme Kinetics of $F B_{1}$ Conversion as a Function of Time and FumD Activity}

\subsection{1. $\mathrm{FB}_{1}$ Leaching into the Aqueous Phase (Water Control Treatment)}

The total mean baseline $\mathrm{FB}_{1}$ levels, i.e., total $\mathrm{FB}_{1}(\mu \mathrm{mol})$ in the "low" and "high" FB contaminated maize incubation mixtures as a function of the different incubation times $(10 \mathrm{~min}, 1 \mathrm{~h}, 4 \mathrm{~h}$ and $24 \mathrm{~h})$ are summarised in Figure 3. A significantly $(p<0.05)$ higher total $\mathrm{FB}_{1}$ was noticed in the total incubation mixture utilising the "high" FB contaminated maize at each time point (Figure $3 \mathrm{~A}$ ). $\mathrm{FB}_{1}$ leaching from "low" FB contaminated maize, reached saturation after $1 \mathrm{~h}$ as, despite that different samples were used, no further increase was noticed in the samples incubated for 4 and $24 \mathrm{~h}$ (Figure 3B). In contrast, 
leaching of $\mathrm{FB}_{1}$ from the "high" $\mathrm{FB}$ contaminated maize, although significantly $(p<0.05)$ lower after $1 \mathrm{~h}$ and $4 \mathrm{~h}$, steadily increased until it mimicked the level of the "low" FB contaminated maize after $24 \mathrm{~h}$.
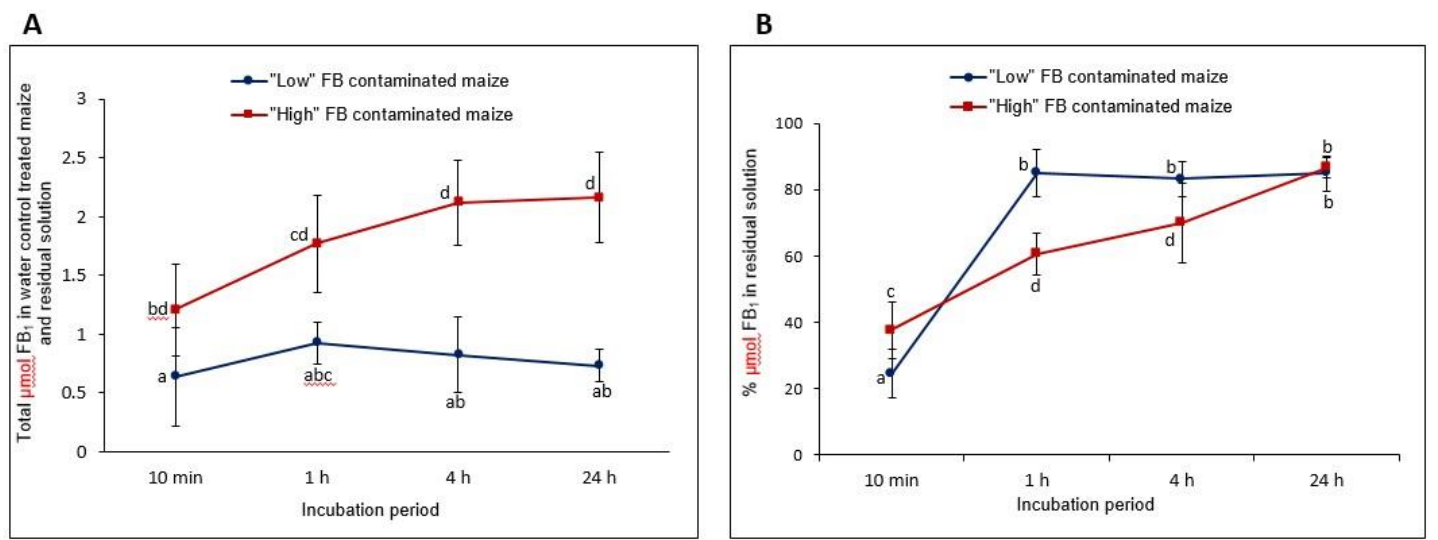

Figure 3. Total amount of $\mathrm{FB}_{1}$ leaching into the incubation mixture in the absence of the enzyme as a function of time, of "low" and "high" FB contaminated maize (A). The \% $\mu$ mol FB 1 leaching into the residual water during a comparable time of incubation (B). Values represent means \pm standard deviations of three to five replications of experiments. Statistical analyses are based on natural log $(\mathrm{ln})$ and differences $(p<0.05)$ between treatment periods within and between "low" and "high" FB contaminated maize are indicated with different letters.

\subsubsection{Comparative Enzyme Kinetics of $\mathrm{FB}_{1}$ Hydrolysis}

The conversion rates of $\mathrm{FB}_{1}$ into $\mathrm{HFB}_{1}$, expressed as $\mathrm{nmol} / \mathrm{min} / \mathrm{mg}$ enzyme, following the 100 and $1000 \mathrm{U} / \mathrm{L}$ FumD incubations as a function of time are summarised in Table 5. The $\mathrm{FB}_{1}$ hydrolysis rates in the presence of $100 \mathrm{U} / \mathrm{L}$ and $1000 \mathrm{U} / \mathrm{L}$ FumD was maximum after $10 \mathrm{~min}$ in both maize samples and was significantly higher $(p<0.05)$ in the "high" FB contaminated maize. The hydrolysis rates decreased from $10 \mathrm{~min}$ to $24 \mathrm{~h}$ in the maize samples for both enzyme activities. The $\mathrm{HFB}_{1}$ formation rate followed the same trend. Overall, the $\mathrm{FB}_{1}$ hydrolyses and $\mathrm{HFB}_{1}$ formation rates were significantly $(p<0.05)$ decreased in the $1000 \mathrm{U} / \mathrm{L}$ as compared to $100 \mathrm{U} / \mathrm{L}$ FumD incubations.

\subsubsection{Comparative of $\mathrm{FB}_{1}$ Hydrolysis to $\mathrm{HFB}_{1}$ Formation Ratios}

There was a significant $(p<0.05)$ difference between the conversion rates $\left(\mathrm{FB}_{1}\right.$ hydrolysis (nmol/min/mg enzyme)) of the 100 and $1000 \mathrm{U} / \mathrm{L}$ FumD incubations during each respective treatment period in both "low" and "high" FB contaminated maize. In both maize batches the 10 min incubation with $100 \mathrm{U} / \mathrm{L}$ exhibited a significant $(p<0.05)$ higher conversion rate when compared with the longer incubations (Table 5). The conversion ratio $\left(\mathrm{FB}_{1}\right.$ hydrolysis: $\mathrm{HFB}_{1}$ formation) also tended to be increased in the "low" compared to the "high" FB contaminated maize with the $100 \mathrm{U} / \mathrm{L}$ incubation. A similar trend in the conversion ratios was obtained during the $1 \mathrm{~h}$ enzyme treatment study at the lower FumD enzyme activities (Table 3). 
Table 5. Enzyme kinetic parameters regarding the conversion of $\mathrm{FB}_{1}$ to $\mathrm{HFB}_{1}$ by different fumonisin esterase FumD activities (U/L) as a function of treatment period (10 min, $1 \mathrm{~h}, 4 \mathrm{~h}$ and $24 \mathrm{~h}$ ) in "low" and "high" FB contaminated maize.

\begin{tabular}{|c|c|c|c|c|c|c|c|c|c|c|c|c|c|c|c|c|}
\hline \multirow[b]{2}{*}{$\begin{array}{l}\text { Treatment } \\
\text { Duration }\end{array}$} & \multicolumn{8}{|c|}{ "Low" FB Contaminated Maize } & \multicolumn{8}{|c|}{ "High" FB Contaminated Maize } \\
\hline & $10 \mathrm{~min}$ & $1 \mathrm{~h}$ & $4 \mathrm{~h}$ & $24 \mathrm{~h}$ & $10 \mathrm{~min}$ & $1 \mathrm{~h}$ & $4 \mathrm{~h}$ & $24 \mathrm{~h}$ & $10 \mathrm{~min}$ & $1 \mathrm{~h}$ & $4 \mathrm{~h}$ & $24 \mathrm{~h}$ & $10 \mathrm{~min}$ & $1 \mathrm{~h}$ & $4 \mathrm{~h}$ & $24 \mathrm{~h}$ \\
\hline $\begin{array}{c}\text { FumD } \\
\text { Activity }\end{array}$ & \multicolumn{4}{|c|}{$\begin{array}{c}\mathrm{FB}_{1} \text { Hydrolysis } \\
\text { (nmol/min/mg Enzyme) }\end{array}$} & \multicolumn{4}{|c|}{$\begin{array}{c}\text { HFB }_{1} \text { Formation * } \\
\text { (nmol/min/mg Enzyme) }\end{array}$} & \multicolumn{4}{|c|}{$\begin{array}{c}\mathrm{FB}_{1} \text { Hydrolysis } \\
\text { (nmol/min/mg Enzyme) }\end{array}$} & \multicolumn{4}{|c|}{$\begin{array}{c}\text { HFB }_{1} \text { Formation * } \\
\text { (nmol/min/mg Enzyme) }\end{array}$} \\
\hline $100 \mathrm{U} / \mathrm{L}$ & $\begin{array}{l}38.34 \\
(1.54)^{\mathrm{a}}\end{array}$ & $\begin{array}{c}8.23 \\
(0.96)^{\mathrm{b}}\end{array}$ & $\begin{array}{l}1.89 \\
(0.04)^{\mathrm{c}}\end{array}$ & $\begin{array}{l}0.32 \\
(0.01)^{\mathrm{d}}\end{array}$ & $\begin{array}{c}20.26 \\
(10.75) \\
\mathrm{A}\end{array}$ & $\begin{array}{l}5.15 \\
(0.80)^{\mathrm{B}}\end{array}$ & $\begin{array}{l}2.12 \\
(0.56)^{\mathrm{C}}\end{array}$ & $\begin{array}{c}0.32 \\
(0.12) \\
D\end{array}$ & $\begin{array}{c}59.19 \\
(12.08)^{\mathrm{i}}\end{array}$ & $\begin{array}{c}13.18 \\
(3.24)^{j}\end{array}$ & $\begin{array}{c}4.42 \\
(1.03)^{\mathrm{e}}\end{array}$ & $\begin{array}{c}0.92 \\
(0.04)^{\mathrm{f}}\end{array}$ & $\begin{array}{c}21.10 \\
(8.56) \\
\mathrm{A}\end{array}$ & $\begin{array}{c}14.55 \\
(1.46) \\
\mathrm{A}\end{array}$ & $\begin{array}{c}4.86 \\
(0.82)^{\mathrm{B}}\end{array}$ & $\begin{array}{c}1.18 \\
(0.16)^{\mathrm{C}}\end{array}$ \\
\hline $1000 \mathrm{U} / \mathrm{L}$ & $\begin{array}{l}3.06 \\
(0.62)^{\mathrm{e}}\end{array}$ & $\begin{array}{c}0.89 \\
(0.11)^{\mathrm{f}}\end{array}$ & $\begin{array}{c}0.20 \\
(0.01)^{\mathrm{g}}\end{array}$ & $\begin{array}{c}0.03 \\
(0.00)^{\mathrm{h}}\end{array}$ & $\begin{array}{l}2.78 \\
(1.55)^{\mathrm{C}}\end{array}$ & $\begin{array}{c}0.87 \\
(0.16)^{\mathrm{E}}\end{array}$ & $\begin{array}{c}0.25 \\
(0.12)^{\mathrm{D}} \\
\end{array}$ & $\begin{array}{c}0.04 \\
(0.01)^{\mathrm{F}}\end{array}$ & $\begin{array}{c}4.53 \\
(2.26) \mathrm{e}\end{array}$ & $\begin{array}{c}1.70 \\
(0.19)^{\mathrm{k}}\end{array}$ & $\begin{array}{c}0.52 \\
(0.05)^{1}\end{array}$ & $\begin{array}{c}0.10 \\
(0.00)^{\mathrm{m}}\end{array}$ & $\begin{array}{c}3.64 \\
(2.02)^{\mathrm{B}} \\
\end{array}$ & $\begin{array}{c}1.98 \\
(0.46)^{\mathrm{C}}\end{array}$ & $\begin{array}{l}0.67 \\
(0.21)^{\mathrm{E}} \\
\end{array}$ & $\begin{array}{c}0.11 \\
(0.02)^{\mathrm{D}}\end{array}$ \\
\hline \multicolumn{9}{|c|}{$\mathrm{FB}_{1}$ Hydrolysis: $\mathrm{HFB}_{1}$ Formation Ratio } & \multicolumn{8}{|c|}{$\mathrm{FB}_{1}$ Hydrolysis: $\mathrm{HFB}_{1}$ Formation Ratio } \\
\hline $100 \mathrm{U} / \mathrm{L}$ & $\begin{array}{l}3.46 \\
(1.93) \mathrm{p}\end{array}$ & $\begin{array}{c}1.39 \\
(0.62) \mathrm{pq}\end{array}$ & $\begin{array}{c}0.95 \\
(0.30) \mathrm{qr}\end{array}$ & $\begin{array}{l}0.93 \\
(0.36)^{\mathrm{pr}}\end{array}$ & - & - & - & - & $\begin{array}{c}1.94 \\
(0.16)^{\mathrm{pr}}\end{array}$ & $\begin{array}{c}0.91 \\
(0.20) \mathrm{pq}\end{array}$ & $\begin{array}{c}0.91 \\
(0.14) \mathrm{qr}\end{array}$ & $\begin{array}{c}0.95 \\
(0.33) \mathrm{qr}\end{array}$ & - & - & - & - \\
\hline $1000 \mathrm{U} / \mathrm{L}$ & $\begin{array}{c}1.45 \\
(0.94)^{\mathrm{pqs}}\end{array}$ & $\begin{array}{c}1.04 \\
(0.16)^{\mathrm{pq}}\end{array}$ & $\begin{array}{c}0.93 \\
(0.38) \mathrm{qr}\end{array}$ & $\begin{array}{c}0.92 \\
(0.35)^{\mathrm{qr}}\end{array}$ & - & - & - & - & $\begin{array}{c}1.10 \\
(0.29)^{\mathrm{pqs}}\end{array}$ & $\begin{array}{c}0.91 \\
(0.26)^{\text {qrs }}\end{array}$ & $\begin{array}{c}0.84 \\
(0.26)^{\mathrm{qrs}}\end{array}$ & $\begin{array}{c}0.92 \\
(0.24) \mathrm{qrs}\end{array}$ & - & - & - & - \\
\hline
\end{tabular}

The statistical analyses are based on natural $\log (\ln )$ transformations. Values represent means of three to five replications of experiments with standard deviations indicated in brackets. Statistical differences $(p<0.05)$ of $\mathrm{FB}_{1}$ hydrolysis rates and conversion ratios between FumD treatments (columns) as a function of time (rows) and for "low" and "high" FB contaminated maize are indicated with different lower case letters. Statistical differences $(p<0.05)$ of $\mathrm{HFB}_{1}$ formation rates between FumD treatments (columns) as a function of time (rows) and for "low" and "high" FB contaminated maize are indicated with different uppercase letters. *Corrected for HFB 1 concentrations obtained in control (0 U/L) treatments in "low" and "high" FB contaminated maize and residual enzyme solutions. $100 \mathrm{U} / \mathrm{L}$ and $1000 \mathrm{U} / \mathrm{L}$ FumD represent 7.5 and $75 \mathrm{mg} / \mathrm{L}$ specific activity, respectively. 


\section{Discussion}

Bioremediation, utilising enzymes for detoxification and/or degradation of environmental chemicals has become an intuitive way to reduce the risk of exposure in animals and humans. A popular approach is to use enzymes that can bind with high affinity toxic compounds and catalyze their hydrolysis, thereby abandoning or reducing their toxicity [27]. The present study established an enzymatic method for FB reduction utilizing fumonisin esterase FumD in whole maize intended for human consumption. The method involved treatment of "low" and "high" FB contaminated home-grown maize with varying FumD activities in solution as a function of time. FumD has been proved effective as a feed enzyme when incorporated into ground maize at a concentration of $40 \mathrm{U} / \mathrm{kg}$ feed [23]. In the current method, FumD was applied to whole maize, therefore the accessibility of FB would be expected to require higher FumD activities and longer incubation times for reduction than with ground maize. However, a major advantage of the current FumD FB reduction method is that the bulk of the residual enzyme and hydrolysed less toxic $\mathrm{HFB}_{1}$ product are not associated with the treated maize kernels, which could find application when considering the reduction of FBs in food intended for human consumption.

Despite the fact FumD treatments were performed in the current reduction method at sub-optimal $\mathrm{pH}$ (approximately $\mathrm{pH} 5$ to 5.5$)$ and ambient temperature $\left( \pm 23^{\circ} \mathrm{C}\right)$ conditions [optimal enzyme activity is obtained at $\mathrm{pH} 8$ and $30^{\circ} \mathrm{C}$ [14], effective hydrolysis of $\mathrm{FB}$ was observed in both maize batches. Treatment with $1000 \mathrm{U} / \mathrm{L}$ FumD effectively hydrolysed FB in "low" and "high" FB contaminated maize resulting in $\geq 80 \%$ reduction in the total FB levels after $1 \mathrm{~h}$ while lower enzyme activities ( $\leq 100 \mathrm{U} / \mathrm{L})$ were less effective. At lower enzyme activities large variations in the FB levels and hydrolyses rates were noticed, which could be related to (i) sample variation within maize batches, (ii) enzyme and/or substrate availability as a function of time, and (iii) the formation of partially hydrolysed FB (PHFB) [28], which will be present as transient intermediates to the completely hydrolysed molecule at high enzyme activities. A significant $(p<0.05)$ decrease of $\mathrm{FB}_{1}$ reduction in the "low" FB contaminated maize was noticed already at $10 \mathrm{U} / \mathrm{L}$ FumD compared to the $100 \mathrm{U} / \mathrm{L}$ in the "high" FB contaminated maize. These differences could be related to the FumD activities applied, $\mathrm{FB}_{1}$ availability at the kernel/aqueous interphase and the formation of PHFB, and will be discussed below.

When considering differences in the formation of $\mathrm{HFB}_{1}$ into the residual enzyme solution, maximum levels were already noticed from $100 \mathrm{U} / \mathrm{L}$ FumD activity. This suggests that some of the hydrolysed product is retained within the maize matrix as well as the possible formation of $\mathrm{PHFB}_{1}$. This became apparent as, although $\mathrm{HFB}_{1}$ was mainly associated $(>90 \%)$ with the residual enzyme solution at low enzyme activities (10 and $100 \mathrm{U} / \mathrm{L}$ ), it tends to accumulate in the "high" and to a lesser extent in the "low" FB contaminated maize kernels at incubations using increased FumD activities $(\geq 1000 \mathrm{U} / \mathrm{L})$. This could be ascribed to the formation of $\mathrm{HFB}_{1}$ and $\mathrm{PHFB}_{1}$ in the inner layers of the maize kernel matrix as compared to the "low" FB contaminated maize, where it mainly occurred on the surface.

As mentioned above, differences occurred in the extent of $\mathrm{FB}_{1}$ hydrolysis between the two samples when considering the $\% \mathrm{FB}_{1}$ loss in the maize as well as the $\mathrm{FB}_{1}$ hydrolysis to $\mathrm{HFB}_{1}$ formation ratio in the incubation mixture, specifically at the lower FumD enzyme activities. These differences were also noticed when considering the enzyme kinetics of $\mathrm{FB}_{1}$ hydrolysis and $\mathrm{HFB}_{1}$ formation rates at 100 and $1000 \mathrm{U} / \mathrm{L}$ FumD activities, which were significantly $(p<0.05)$ increased in the "high" FB contaminated maize. The higher $\mathrm{FB}_{1}$ conversion rate obtained with the $100 \mathrm{U} / \mathrm{L}$ FumD activity as compared to the $1000 \mathrm{U} / \mathrm{L}$ enzyme activity is related, as mentioned above, to FB availability and/or the limitation thereof when utilising excess enzyme activities.

The level of FB contamination determined the hydrolysis rate implying that fungal infiltration and FB production inside the kernel are key rate limiting factors. This became evident as Fusarium spp. infects maize with the fumonisins concentrated in the pericarp and embryo of the maize kernel [29], while in damaged kernels the fungus is likely to penetrate deeper into the kernel, contaminating the endosperm [30-32]. It is known that leaching of substances from the maize endosperm occurs 
during absorption of water while damage to the kernel pericarp increases leaching early during water absorption [33].

Differences in $\mathrm{FB}_{1}$ hydrolysis rates between the "low" and "high" FB contaminated maize batches are therefore likely to depend on the leaching of $\mathrm{FB}_{1}$ from the maize kernel and the interaction of FumD at the kernel outer layer/aqueous inter phase. This became apparent when considering the $\%$ $\mathrm{FB}_{1}$ hydrolysis in the "low" FB contaminated sample that reached a maximum already after $100 \mathrm{U} / \mathrm{L}$ compared to the "high" FB contaminated maize reaching a maximum at $1000 \mathrm{U} / \mathrm{L}$. This implies that the $\mathrm{FB}_{1}$ became depleted as a substrate for the enzyme much earlier. This was also evident as leaching of $\mathrm{FB}_{1}$ into the water control was faster from the "low" FB contaminated maize at 1 and $4 \mathrm{~h}$ of incubation compared to a more gradual effect considering the "high" FB contaminated maize. The gradual increased leaching of $\mathrm{FB}_{1}$ from the "high" FB contaminated maize could be related to the extent of fungal damage of the kernels that will determine the diffusion rate of $\mathrm{FB}_{1}$ from the inner layers. Therefore, the higher initial (10 min) conversion rate of $\mathrm{FB}_{1}$ in the "high" as compared to "low" FB contaminated maize is facilitated by the accessibility of $\mathrm{FB}_{1}$ associated with the inner as well as outer layers. The location of $\mathrm{FB}_{1}$ in the kernel and the leaching rate into the aqueous enzyme-solution could therefore affect the efficacy of FB conversion rates and substrate to product ratios as noticed in the current study. However, the efficacy of FumD is not only determined by the concentration of $\mathrm{FB}_{1}$ leaching into the aqueous phase but could also depend on the enzyme penetration into the endosperm which could explain the differences in FB conversion rates between "low" and "high" FB contaminated maize. This became evident as an increased $\%$ of $\mathrm{HFB}_{1}$ was noticed in the maize kernels when utilising higher FumD activities. Therefore, depending on the extent of fungal damage and FB contamination to the maize pericarp/endosperm, a specific FumD activity seems to be required for maximum $\mathrm{FB}_{1}$ hydrolysis, yielding a 1:1 $\mathrm{FB}_{1}$ hydrolysis to $\mathrm{HFB}_{1}$ formation ratio. This would become important when considering the application of the enzyme in different technological approaches utilising maize samples with varying FB contamination levels.

From a technological perspective, enzymatic detoxification of FB has been utilised effectively in the animal feed industry $[21,22,24]$, while very little is known about possible applications to reduce exposure in humans. In this regard, commercial maize-based manufacturing processes, including dry milling and ethanol production are challenged with maintaining regulatory levels for FB in products and co-products $[29,34]$. During dry milling the FB mycotoxins are known to be \pm 3 -fold concentrated in the surface layers and are mainly confined to the total hominy feed fractions, which are mainly used in animal feed or non-food products [29]. As most micronutrients are concentrated in total hominy feed and a large portion of maize grain is lost in this fraction [35], FB decontamination could be of value with respect to human food. It could also find application during ethanol production, as the co-products wet and dry distillers' grains and solubles, containing high levels of FB, are increasingly being marketed as protein-rich and cost-saving inclusion in livestock and poultry feed [34]. Therefore, possible economic advantages of the FumD FB reduction method for commercial maize-based manufacturing processes should be further investigated.

The FumD FB reduction method in maize could also find application in communities utilising home-grown maize as a main dietary staple and known to be exposed above the tolerable daily intake levels, i.e., a PMTDI of $2 \mu \mathrm{g} / \mathrm{kg} / \mathrm{bw} /$ day [36,37]. To decrease the risk of FB exposure, culturally sensitive, practical and biologically based methods of reduction are relevant and need to be implemented [1]. In the current study, the "low" FB contaminated maize contained FB levels below the regulatory maximum levels for fumonisins in maize (total $\mathrm{FB}_{1}$ and $\mathrm{FB}_{2} 4000 \mu \mathrm{g} / \mathrm{kg}$ ) set by the Codex Alimentarius Commission [38], while the high FB contaminated samples exceeded that. These maize batches were therefore ideal to evaluate the newly designed FumD FB reduction method, which could find application in maize subsistence farming communities where exposure to high levels of FB is the norm on a daily basis [37,39]. Of interest is that the bulk of $\mathrm{HFB}_{1}$ resides into the aqueous phase, which will further minimize exposure to, not only $\mathrm{FB}_{1}$, but also to the less toxic breakdown product, $\mathrm{HFB}_{1}$. 
However, increased amounts (up to $32 \%$ ) of $\mathrm{HFB}_{1}$ accumulated in "high" FB contaminated maize in the presence of increased FumD activities.

Recently a practical and culturally sensitive maize hand-sorting and water wash intervention method resulted in $84 \%$ reduction of $\mathrm{FB}_{1}$ levels [40]. In the current study, the $1000 \mathrm{U} / \mathrm{L}$ FumD treatment resulted in access of $80 \%$ reduction in total FBs in both "low" and "high" FB contaminated samples. However, as only approximately $10 \%$ of FB is removed from the maize kernels during the water wash procedure [41], the newly developed FumD FB reduction method could effectively be applied to further reduce $\mathrm{FB}$ exposure prior to food preparation.

\section{Conclusions}

The present study developed an innovative FumD FB reduction method in whole maize. The method is suitable for direct application in the food chain postharvest, resulting in the reduction of $\mathrm{FB}_{1}$ with the formation of the hydrolysed breakdown product, $\mathrm{HFB}_{1}$, mainly associated with the aqueous phase to be discarded. Reduction of FB in contaminated maize could have a positive impact on food safety and security as well as having economic benefits during manufacturing processes.

\section{Materials and Methods}

\subsection{Chemicals}

Methanol, acetonitrile, formic acid (HPLC grade) and Whatman filter paper were obtained from Merck (Kenilworth, NJ, USA). Water for all experiments was successively purified by reverse osmosis followed by Milli-Q water purification (Millipore, Burlington, MA, USA).

\subsection{Fumonisin Standard Solutions}

Pure analytical standards of $\mathrm{FB}_{1}, \mathrm{FB}_{2}, \mathrm{FB}_{3}$ and $\mathrm{HFB}_{1}$ (purity $>97 \%$ ) were prepared at the Institute of Biomedical and Microbial Biotechnology of the Cape Peninsula University of Technology, South Africa, according to the methods of Cawood et al. [42] and Gelderblom et al. [13]. Stock solutions of the individual purified fumonisin standards were prepared $\left(1 \mathrm{mg} / \mathrm{mL}\right.$ in acetonitrile- $\left.\mathrm{H}_{2} \mathrm{O}(1: 1)\right)$ and aliquots used to prepare an evaporated working solution containing the fumonisin standards at individual concentrations of $5 \mu \mathrm{g} / \mathrm{mL}$. For compiling matrix-matched calibration curves, five working standard dilutions were prepared with blank maize matrix extract as solvent, as described below.

\subsection{Maize Sample Collection}

Home-grown maize was collected in the Centane, Mnquma Local Municipality (areas of the former Transkei region) of the Eastern Cape Province, South Africa from households of subsistence maize farmers. "Good" home-grown whole maize was collected directly from visibly healthy batches destined for human consumption. "Mouldy" home-grown whole maize was collected directly from "mouldy" batches destined for chicken/livestock feed. The "good" and "mouldy" maize batches were labelled "low" and "high" FB contamination, respectively. Each maize batch was thoroughly mixed and kept at $4{ }^{\circ} \mathrm{C}$ until analysed. Control maize containing no fumonisins, was obtained from the Southern African Grain Laboratory (Pretoria, South Africa) and used for the preparation of a maize extract used for matrix-matched calibration curves.

\subsection{FumD Enzyme Preparation}

A fumonisin esterase, designated FumD (EC 3.1.1.87; FUMzyme ${ }^{\circledR}$ ), was obtained from BIOMIN (Tulln, Austria) with a specific activity of $13,400 \mathrm{U} / \mathrm{g}$. One unit is the enzymatic activity defined to release $1 \mu \mathrm{mol}$ tricarballylic acid per minute from $100 \mu \mathrm{M} \mathrm{FB}_{1}$ in $20 \mathrm{mM}$ Tris- $\mathrm{HCl}$ buffer $\mathrm{pH} 8.0$ containing $0.1 \mathrm{mg} / \mathrm{mL}$ bovine serum albumin at $30{ }^{\circ} \mathrm{C}$. A stock enzyme solution $(400 \mathrm{U} / \mathrm{mL})$ was prepared in the Tris-HCl buffer and used in all experiments. 


\subsection{The FumD FB Reduction Method}

Enzyme solutions utilised were prepared in distilled water from the FumD stock solution. Maize kernels (100 g) of the "low" and "high" FB contaminated maize batches were weighed in Erlenmeyer flasks $(500 \mathrm{~mL})$ and enzyme solution added $(200 \mathrm{~mL})$, obtaining a maize to solvent ratio of 1:2. Samples were mixed at $80 \mathrm{rpm}$ on a shaker (New Brunswick Scientific, Edison Township, NJ, USA) at ambient temperature $\left( \pm 23^{\circ} \mathrm{C}\right)$ for different incubation periods. The residual enzyme solution was decanted and stored at $-20^{\circ} \mathrm{C}$ until analysed, while the residual maize kernels were dried onto laboratory paper towels at ambient temperature for $48 \mathrm{~h}$. Residual maize kernel samples were ground in a laboratory mill (Falling Number AB, Stockholm, Sweden) to a fine meal and kept in airtight containers at $-20^{\circ} \mathrm{C}$ until analysed. Three to five replicates were included for each treatment.

\subsection{FumD Incubation Protocols}

To obtain the optimal enzyme activity required for FB hydrolysis the maize samples were incubated with different FumD activities (10, 100, 1000 and 5000 U/L) for $1 \mathrm{~h}$ as described above. The $\mathrm{pH}$ values of the maize-enzyme solutions were determined before and after the incubation treatment. In a follow-up experiment two FumD activities (100 and $1000 \mathrm{U} / \mathrm{L}$ ) were used, and incubations were carried out over varying time periods including $10 \mathrm{~min}, 1 \mathrm{~h}, 4 \mathrm{~h}$ and $24 \mathrm{~h}$ to investigate the FB hydrolysis kinetics. Reference water control incubations were included in each experiment. All samples were processed and stored as described above.

\subsection{Analyses of FB and $H F B_{1}$ Concentrations in Maize and Residual Solutions}

$\mathrm{FB}_{1}, \mathrm{FB}_{2}, \mathrm{FB}_{3}$ and $\mathrm{HFB}_{1}$ concentrations were determined in the (i) untreated "low" and "high" $\mathrm{FB}$ contaminated maize batches (five replicates), (ii) the water control and enzyme treated residual maize kernel samples, and (iii) residual water control and enzyme solutions (3-5 replicate experiments).

\subsubsection{Extraction Methods}

$\mathrm{FB}$ and $\mathrm{HFB}_{1}$ were extracted from maize according to the method of Sewram et al. [43] with minor modifications. Briefly, $100 \mathrm{~mL}$ of extraction solvent [methanol: acetonitrile: water (25:25:50; v/v/v)] was added to ground maize kernels $(10 \mathrm{~g})$ and placed on a shaker $(80 \mathrm{rpm})$ for $20 \mathrm{~min}$. The extracts were subsequently centrifuged $(4000 \times g)$ in a refrigerated Sorvall RC-3B centrifuge (DuPont, Norwalk, $\mathrm{CT}$, USA) at $4{ }^{\circ} \mathrm{C}$ for $10 \mathrm{~min}$. The supernatant $(20 \mathrm{ml})$ was diluted (1:1) with methanol:water (25:75), filtered (Whatman No 4 filter paper) and filtrates analyzed by direct injection into the LC-MS/MS. FAPAS (London, UK) quality control reference maize samples (Cat no T22123QC), containing the mycotoxins in known concentration ranges were included. For analyses of the residual solutions, samples were filtered (Whatman No 4 filter paper) and filtrates analysed directly by LC-MS/MS. Matrix-matched standard solutions for calibration curves were prepared utilising an extract prepared from control maize.

\subsubsection{Chromatographic Quantification of $\mathrm{FB}$ and $\mathrm{HFB}_{1}$}

Quantification of $\mathrm{FB}$ and $\mathrm{HFB}_{1}$ in maize extracts and residual enzyme solutions was performed by the Mass Spectrometry Unit of the Central Analytical Facility of Stellenbosch University, South Africa. The mycotoxins were separated on a reversed-phase BEH $\mathrm{C}_{18}$ column $(2.1 \times 100 \mathrm{~mm}$; particle size $1.7 \mu \mathrm{m}$ ) (Waters, Milford, MA, USA) and analysed with positive electrospray ionisation (EI) in the multiple reaction monitoring (MRM) mode in a Waters Acquity Ultra high performance Liquid Chromatograph (UPLC) coupled to a Tandem Quadrupole Mass spectrometer (Waters Xevo TQ MS). Eluent $A$ was water and eluent $B$ was methanol, both containing $0.1 \%$ formic acid. The chromatographic method held the initial mobile phase composition (15\% B) constant for $2 \mathrm{~min}$, followed by a linear gradient to $100 \% \mathrm{~B}$ within $3 \mathrm{~min}$. This final condition was held for $3.30 \mathrm{~min}$, followed by $8 \mathrm{~min}$ of column re-equilibration at $15 \% \mathrm{~B}$. The flow rate of the mobile phase was $0.35 \mathrm{ml} / \mathrm{min}$. For each 
compound, one precursor and two product ions were monitored, one product ion for quantification and one for confirmation. A calibration curve consisting of five matrix-matched standards for each mycotoxin was used for quantification.

\subsubsection{Validation of the Extraction and FB Quantification Methods}

The extraction and chromatographic methods were validated by determining the LOQ, linearity $\left(\mathrm{r}^{2}\right)$ of the calibration curve, selectivity, accuracy, and \% recovery according to guidelines of the United States Department of Health and Human Services, Food and Drug Administration [44].

\subsection{Statistical Analyses}

The NCSS Version 11 software [45] was used for statistical analysis. Data were subjected to natural $\log (\ln )$ transformation of all variables and analysed within a generalised linear model ANOVA. Multiple comparisons were analysed using the Tukey-Kramer's multiple comparison procedure. This method provides joint simultaneous confidence intervals for all pairwise differences between the means; and also provides the multiple comparison $p$-value. Generally, $p<0.05$ was used as statistical significance. In addition, the size of the F-ratios was used to measure relative sizes of differences.

Author Contributions: Data curation, J.A. and W.G.; Formal analysis, J.A. and I.D.; Funding acquisition, J.A.; Methodology, J.A., G.S., W.-D.M., J.R., H.-M.B., G.S. and W.G.; Resources, G.S., W.-D.M., J.R. and H.-M.B.; Supervision, J.A.; Validation, J.A.; Writing-original draft, J.A. and I.D.; Writing-review \& editing, J.A., G.S., W.-D.M., J.R., H.-M.B., G.S. and W.G.

Funding: This research was funded by the South African Maize Trust (Project MTM 13/04).

Acknowledgments: The authors thank the South African Maize Trust for their financial support of research on enzymatic methods for reduction of mycotoxin concentrations in maize.

Conflicts of Interest: The authors declare no conflict of interest.

\section{References}

1. Alberts, J.F.; van Zyl, W.H.; Gelderblom, W.C.A. Biologically based methods for control of fumonisin-producing Fusarium species and reduction of the fumonisins. Front. Microbiol. 2016, 7, 548. [CrossRef] [PubMed]

2. Yates, I.E.; Meredith, F.; Smart, W.; Bacon, C.W.; Jaworski, A.J. Trichoderma viride suppresses fumonisin $B_{1}$ production by Fusarium moniliforme. J. Food Prot. 1999, 62, 1326-1332. [CrossRef] [PubMed]

3. Bacon, C.W.; Yates, I.E.; Hinton, D.M.; Meredith, F. Biological control of Fusarium moniliforme in maize. Environ. Health Perspect. 2001, 109, 325-332.

4. Duvick, J. Prospects for reducing fumonisin contamination of maize through genetic modification. Environ. Health Perspect. 2001, 109, 337-342.

5. Duvick, J.; Maddox, J.; Gilliam, J. Composition and methods for fumonisin detoxification. Patent No US6538177, 25 March 2003.

6. Cleveland, T.E.; Dowd, P.F.; Desjardins, A.E.; Bhatnagar, D.; Cotty, P.J. United States Department of Agriculture-Agricultural Research Service research on pre-harvest prevention of mycotoxins and mycotoxigenic fungi in US crops. Pest. Manag. Sci. 2003, 59, 629-642. [CrossRef] [PubMed]

7. Cavaglieri, L.; Passone, A.; Etcheverry, M. Screening procedures for selecting rhizobacteria with biocontrol effects upon Fusarium verticillioides growth and fumonisin $\mathrm{B}_{1}$ production. Res. Microbiol. 2004, 155, 747-754. [CrossRef] [PubMed]

8. Samapundo, S.; De Meulenaer, B.; Osei-Nimoh, D.; Lamboni, Y.; Debevere, J.; Devlieghere, F. Can phenolic compounds be used for the protection of corn from fungal invasion and mycotoxin contamination during storage? Food Microbiol. 2007, 24, 465-473. [CrossRef]

9. Dalie, D.K.; Deschamps, A.M.; Atanasova-Penichon, V.; Richard-Forget, F. Potential of Pediococcus pentosaceus (L006) isolated from maize leaf to suppress fumonisin-producing fungal growth. J. Food Prot. 2010, 73, 1129-1137. [CrossRef] 
10. Bacon, C.W.; Hinton, D.M. In planta reduction of maize seedling stalk lesions by the bacterial endophyte Bacillus mojavensis. Can. J. Microbiol. 2011, 57, 485-492. [CrossRef]

11. Mitchell, N.J.; Xue, K.S.; Lin, S.; Marroquin-Cardona, A.; Brown, K.A.; Elmore, S.E.; Tang, L.; Romoser, A.; Gelderblom, W.C.A.; Wang, J.; et al. Calcium montmorillonite clay reduces $\mathrm{AFB}_{1}$ and $\mathrm{FB}_{1}$ biomarkers in rats exposed to single and co-exposures of aflatoxin and fumonisin. J. Appl. Toxicol. 2014, 34, 795-804. [CrossRef]

12. Alberts, J.F.; Lilly, M.; Rheeder, J.P.; Burger, H.M.; Shephard, G.S.; Gelderblom, W.C.A. Technological and community-based methods to reduce mycotoxin exposure. Food Control. 2017, 73, 101-109. [CrossRef]

13. Gelderblom, W.C.A.; Cawood, M.E.; Snyman, S.D.; Vleggaar, R.; Marasas, W.F.O. Structure-activity relationships of fumonisins in short-term carcinogenesis and cytotoxicity assays. Food Chem. Toxicol. 1993, 31, 407-414. [CrossRef]

14. Heinl, S.; Hartinger, D.; Thamhesl, M.; Kunz-Vekiru, E.; Krska, R.; Schatzmayr, G.; Moll, W.; Grabherr, R. Degradation of fumonisin $B_{1}$ by the consecutive action of two bacterial enzymes. J. Biotechnol. 2010, 145, 120-129. [CrossRef] [PubMed]

15. Duvick, J.; Rood, T.; Maddox, J.; Gilliam, J. Detoxification of mycotoxins in planta as a strategy for improving grain quality and disease resistance: Identification of fumonisin-degrading microbes from maize. In Molecular Genetics of Host-Specific Toxins in Plant Disease, Developments in Plant Pathology; Kohmoto, K., Yoder, O.C., Eds.; Springer International Publishing AG: Basel, Switzerland, 1998; Volume 13, pp. 369-381.

16. Duvick, J.; Rood, T.; Wang, X. Fumonisin detoxification enzymes. Patent No US5716820, 10 February 1998.

17. Blackwell, B.A.; Gilliam, J.T.; Savard, M.E.; Miller, D.; Duvick, J.P. Oxidative deamination of hydrolysed fumonisin $\mathrm{B}_{1}\left(\mathrm{AP}_{1}\right)$ by cultures of Exophiala spinifera. Nat. Toxins 1999, 7, 31-38. [CrossRef]

18. Hartinger, D.; Schwartz, H.; Hametner, C.; Schatzmayr, G.; Haltrich, D.; Moll, W.D. Enzyme characteristics of aminotransferase FumI of Sphingopyxis sp. MTA144 for deamination of hydrolyzed fumonisin $\mathrm{B}_{1}$. Appl. Microbiol. Biotechnol. 2011, 91, 757-768. [CrossRef]

19. Moll, D.; Hartinger, D.; Grießler, K.; Binder, E.M.; Schatzmayr, G. Method for the production of an additive for the enzymatic decomposition of mycotoxins, additive, and use thereof. Patent No US8703460B2, 22 April 2014.

20. Oswald, I.P.; Grenier, B.; Schatzmayr, G.; Moll, W. Enzymatic detoxification of mycotoxins: Hydrolysis of fumonisin $B_{1}$ strongly reduced the toxicity for piglets. In World Nutrition Forum, Nutri Economics: Balancing Global Nutrition and Productivity; Binder, E.M., Ed.; Anytime Publishing: Leicestershire, UK, 2012; pp. $263-271$.

21. BIOMIN. Available online: https://www.BIOMIN.net/en/home/ (accessed on 12 July 2019).

22. Masching, S.; Naehrer, K.; Schwartz-Zimmermann, H.E.; Sãrãndan, M.; Schaumberger, S.; Dohnal, I.; Nagl, V.; Schatzmayr, D. Gastrointestinal degradation of fumonisin $B_{1}$ by carboxylesterase FumD prevents fumonisin induced alteration of sphingolipid metabolism in turkey and swine. Toxins 2016, 8, 84. [CrossRef] [PubMed]

23. Grenier, B.; Bracarense, A.F.L.; Schwartz, H.E.; Lucioli, J.; Cossalter, A.; Moll, W.-D.; Schatzmayr, G.; Oswald, I.P. Biotransformation approaches to alleviate the effects induced by Fusarium mycotoxins in Swine. J. Agric. Food Chem. 2013, 61, 6711-6719. [CrossRef]

24. Grenier, B.; Schwartz, H.E.; Gruber-Dorninger, C.; Dohnal, I.; Aleschko, M.; Schatzmayr, G.; Moll, W.-D.; Applegate, T.J. Enzymatic hydrolysis of fumonisins in the gastrointestinal tract of broiler chickens. Poult Sci. 2017, 96, 4342-4351. [CrossRef]

25. Mogensen, J.M.; Sørensen, S.M.; Sulyok, M.; van der Westhuizen, L.; Shephard, G.S.; Frisvad, J.C.; Thrane, U.; Krska, R.; Nielsen, K.F. Single-kernel analysis of fumonisins and other fungal metabolites in maize from South African subsistence farmers. Food Addit. Contam. 2011, 28, 1724-1734. [CrossRef]

26. Janse van Rensburg, J.; Flett, B.C.; Mc Laren, N.W.; Mc Donald, A.H. Sampling variation in the quantification of fumonisins in maize samples. S. Afr. J. Plant. E Soil 2011, 28, 90-96.

27. Febbraio, F. Biochemical strategies for the detection and detoxification of toxic chemicals in the environment. World J. Biol. Chem. 2017, 8, 13-20. [CrossRef] [PubMed]

28. Hahn, I.; Nagl, V.; Schwartz, H.E.; Varga, E.; Schwartz, C.; Slavik, V.; Reisinger, N.; Malachová, A.; Cirlini, M.; Generotti, S.; et al. Effects of orally administered fumonisin $\mathrm{B}_{1}\left(\mathrm{FB}_{1}\right)$, partially hydrolysed $\mathrm{FB}_{1}$, hydrolysed $\mathrm{FB}_{1}$ and $N$-(1-deoxy-D-fructos-1-yl) $\mathrm{FB}_{1}$ on the sphingolipid metabolism in rats. Food Chem. Toxicol. 2015, 76, 11-18. [CrossRef] [PubMed]

29. Burger, H.-M.; Shephard, G.S.; Louw, W.; Rheeder, J.P.; Gelderblom, W.C.A. The mycotoxin distribution in maize milling fractions under experimental conditions. Int. J. Food Microbiol. 2013, 165, 57-64. [CrossRef] [PubMed] 
30. Brera, C.; Debegnach, F.; Grossi, S.; Miraglia, M. Effect of industrial processing on the distribution of fumonisin $\mathrm{B}_{1}$ in dry milling corn fractions. J. Food Prot. 2004, 67, 1261-1266. [CrossRef] [PubMed]

31. Duncan, K.E.; Howard, R.J. Biology of maize kernel infection by Fusarium verticillioides. Mol. Plant. Microbe Interact. 2010, 23, 6-16. [CrossRef] [PubMed]

32. Kent, N.L.; Evers, D. Dry Milling. In Kent's Technology of Cereals. An Introduction for Students of Food Science and Agriculture, 5th ed.; Rosenstrater, K., Evers, A., Eds.; Woodhead Publishing: Cambridge, UK, 2017; pp. 421-514.

33. Bruggink, H.; Kraak, H.L.; Dijkema, M.H.G.E.; Bekendam, J. Some factors influencing electrolyte leakage from maize (Zea mays L.) kernels. Seed Sci. Res. 1991, 1, 15-20. [CrossRef]

34. Wu, F.; Munkvold, G.P. Mycotoxins in Ethanol Co-products: Modeling Economic Impacts on the Livestock Industry and Management Strategies. J. Agric. Food Chem. 2008, 56, 3900-3911. [CrossRef]

35. Ranum, P.; Pena-Rosas, J.P.; Garcia-Casal, M.N. Global maize production, utilization, and consumption. Ann. N. Y. Acad. Sci. 2014, 1312, 105-112. [CrossRef]

36. Burger, H.-M.; Lombard, M.J.; Shephard, G.S.; Danster-Christians, N.; Gelderblom, W.C.A. Development and evaluation of a sensitive mycotoxin risk assessment model (MYCORAM). Toxicol. Sci. 2014, 141, 387-397. [CrossRef]

37. Shephard, G.S.; Burger, H.-M.; Rheeder, J.P.; Alberts, J.F.; Gelderblom, W.C.A. The effectiveness of regulatory maximum levels for fumonisin mycotoxins in commercial and subsistence maize crops in South Africa. Food Control. 2019, 97, 77-80. [CrossRef]

38. FAO. Maximum Levels of Fumonsisin in Maize and Maize Products, Codex Alimentarius Commission, Geneva. Available online: http://www.fao.org/news/story/en/item/238558/icode/ (accessed on 30 May 2019).

39. Alberts, J.; Rheeder, J.; Gelderblom, W.; Shephard, G.; Burger, H.-M. Rural subsistence maize farming in South Africa: Risk assessment and intervention models for reduction of exposure to mycotoxins. Toxins 2019, 11, 334. [CrossRef]

40. Van der Westhuizen, L.; Shephard, G.S.; Burger, H.M.; Rheeder, J.P.; Gelderblom, W.C.; Wild, C.P.; Gong, Y.Y. Fumonisin $B_{1}$ as a urinary biomarker of exposure in a maize intervention study among South African subsistence farmers. Cancer Epidemiol. Prev. Biomark. 2011, 20, 483-489. [CrossRef]

41. Van der Westhuizen, L.; Shephard, G.S.; Rheeder, J.P.; Burger, H.-M.; Gelderblom, W.C.A.; Wild, C.P.; Gong, Y.Y. Optimising sorting and washing of home-grown maize to reduce fumonisin contamination under laboratory-controlled conditions. Food Control. 2011, 22, 396-400. [CrossRef]

42. Cawood, M.E.; Gelderblom, W.C.A.; Vleggaar, R.; Behrend, Y.; Thiel, P.; Marasas, W.F.O. Isolation of the fumonisins: A quantitative approach. J. Agric. Food Chem. 1991, 39, 1958-1962. [CrossRef]

43. Sewram, V.; Shephard, G.S.; Marasas, W.F.O.; De Castro, M.F.P.M. Improving extraction of fumonisin mycotoxins from Brazilian corn-based infant foods. J. Food Prot. 2003, 66, 854-859. [CrossRef]

44. United States Department of Health and Human Services, Food and Drug Administration (US FDA). USA Guidance for Industry. Bioanalytical Method Validation. Available online: https:/www.fda.gov/regulatoryinformation/search-fda-guidance-documents/bioanalytical-method-validation-guidance-industry (accessed on 30 May 2019).

45. NCSS 11 Statistical Software. Available online: http://ncss.com/software/ncss (accessed on 30 May 2019).

(C) 2019 by the authors. Licensee MDPI, Basel, Switzerland. This article is an open access article distributed under the terms and conditions of the Creative Commons Attribution (CC BY) license (http://creativecommons.org/licenses/by/4.0/). 